\title{
CURRENT STATE AND NEW TRENDS IN THE QUATERNARY GEOLOGY OF THE BALTIC STATES
}

\author{
Anto RAUKAS a, Ojars ĀBOLTINS b, and Algirdas GAIGALAS c
}

a Eesti Teaduste Akadeemia Geoloogia Instituut (Institute of Geology, Estonian Academy of Sciences), Estonia pst. 7, EE-0100 Tallinn, Eesti (Estonia)

b Latvijas Universitāte, geogrāfijas fakultāte (Faculty of Geography, University of Latvia), Raina bulv. 19, LV-1098, Riga, Latvija (Latvia)

c Vilniaus universitetas, geologijos ir mineralogijos katedra (Department of Geology and Mineralogy, Vilnius University), Ciurlionio 21/27, LT-2009, Vilnius, Lietuva (Lithuania)

Received 8 August 1994, accepted 27 September 1994

Abstract. The Baltic States have a long history of Quaternary geological investigations. Studies have proved successful in many fields of research, including stratigraphy, geomorphology, lithology, isotopic investigations, etc. Medium-scale mapping of the area has been completed and large-scale mapping is in progress. Several modern research methods (scanning electron microscopy; ESR, ${ }^{14} \mathrm{C}$, OSL, and $\mathrm{TL}$ dating; stable isotopes) are applied. In 1993 a new regional stratigraphic scheme of the Quaternary deposits on the Baltic States as a whole, and local stratigraphic schemes for all the three republics (Estonia, Latvia, and Lithuania) were accepted. Most of the genetic types of sediments, such as tills, glaciofluvial and glaciolacustrine deposits, have been thoroughly studied, with some groups of landforms described in particular detail. An important task facing the researchers is the change-over from the Eastern European to the Western European standards and terminology.

Key words: Baltic States, Quaternary geology, topography, structure of the Pleistocene cover, deglaciation history, Baltic Sea, river activity, human impact.

\section{INTRODUCTION}

The area of the Baltic States, which comprises Estonia (45 $200 \mathrm{sq} \mathrm{km})$, Latvia (61600 sq km), and Lithuania (65200 sq km), was shaped by continental glaciers. The Baltic Sea has also notably influenced the evolution of the area. It has been inhabited for more than ten thousand years. The data available show a very close settlement dependent on the evolution of the ice-dammed lakes, the Baltic Sea, and the river activity.

The Baltic States have a long and rather well-known history of Quaternary geological investigations. The foundation of universities in Vilnius (1579) and Tartu (1632) was an important step forward in the development of natural sciences. As early as in the middle of the last century, Eichwald (1853), zoologist and palaeontologist of the universities of Tartu and Vilnius, who was later to become a member of the St. Petersburg Academy, supposed that at least the northern part of Estonia's territory had once been covered with a glacier. Grewingk (1879) maintained that the Baltic States had been at least twice covered with ancient active glaciers, which shaped the topography and left

(c) Ecsti TA Toimetised. Geoloogia, 1995 Eesti 
behind tills with different colour and lithological composition. Hausen (1913) reconstructed the course of the glacial retreat during the last glaciation in the eastern Baltic. He compiled several high-quality palaeogeographical schemes, which showed successive locations of the glacier margin and ice-dammed lakes. Schmidt (1869) was the first to find in beach deposits of West Estonia remains of the fresh water snail Ancylus fluviatilis. This inspired Munthe (1910) to establish the fresh-water pre-Litorina stage in the history of the Baltic.

Up till now the eastern Baltic area has served as a key region in solving many topical problems of the Quaternary history (Гуделис, 1973; Даниланс, 1973; Раукас, 1978). Today a set of geological maps of a scale 1:200000 (including those of Quaternary deposits, geomorphology, and bedrock topography) are available on all the three Baltic States. The mapping of vast areas at scales of $1: 25000$ and $1: 50000$ is under way. Modern investigation methods, including scanning electron microscopy as well as ESR, ${ }^{14} \mathrm{C}$, OSL, and TL dating methods, stable isotopes etc., are used. The vast majority of genetic types of sediments and certain landforms have been described in detail.

The main purpose of the present paper is to summarize the most recent results obtained in the field of the Quaternary geology in the Baltic States before the XIV Congress of the International Union for Quaternary Research (INQUA), which will be held in Berlin on 3-10 August 1995. It also attempts to impart information to the participants of the scientific excursion of the INQUA Congress through the Baltic States (11-22 August 1995).

\section{STRUCTURAL POSITION}

Structurally, the territory of the Baltic States belongs to the northwestern part of the East-European Platform. The boundary between the Fennoscandian Shield and the Platform is determined by the northern limit of sedimentary rocks. It runs through the Gulf of Finland. Depending on tectonic peculiarities, the bedrock of different age crops out more or less in the form of sublatitudinal belts, starting from Vendian and Cambrian rocks in the north (North Estonia) and ending with Mesozoic and Neogene rocks in the south (Lithuania).

The distribution of all Quaternary sediments in this territory is highly controlled by the topography and composition of the local bedrock. Basing on the content of local and allochthonous material, the lodgement tills in the Baltic area can be subdivided into local, transitional, and erratic varieties (Гайгалас, 1969). In the transitional lodgement tills local sedimentary material predominates. Aqueoglacial sediments, derived from tills, are somewhat impoverished in local material, transported mostly from a distance of $10-20 \mathrm{~km}$ (Раукас et al., 1971).

\section{BEDROCK TOPOGRAPHY}

The surface of the rather thoroughly studied bedrock has been shaped during the long continental period, which in the northern part of the investigated area has lasted from the Late Palaeozoic up to the present. The Pleistocene glaciations and recent exogenous processes have finally formed the uneven bedrock topography (Fig. 1), where lowlands (less than $40 \mathrm{~m}$ over the contemporary sea level) alternate with plateaus $(40-80 \mathrm{~m})$ and uplands (over $80 \mathrm{~m}$ ). The main erosional features of the bedrock topography are clearly reflected in the present- 
day landforms, especially in the northern Baltic. Many lake basins (Peipsi, Võrtsjärv, Burtnieki) have developed in shallow bedrock depressions, reworked by glaciers. Elevations (Pandivere, Sakala, Aluksne, Vidzeme) have often a bedrock core. The bedrock relief has exercised also a certain impact on the distribution of ice marginal

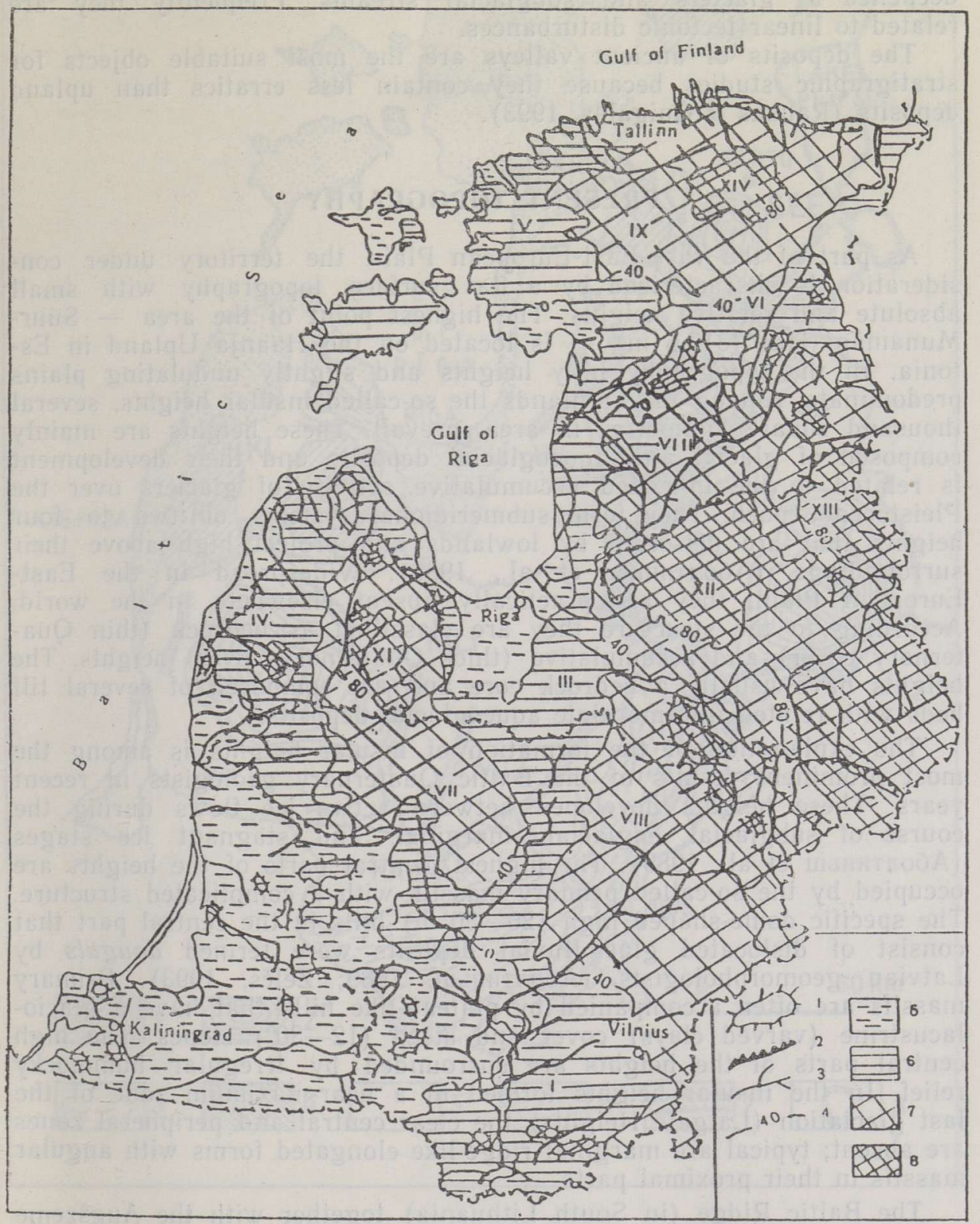

Fig. 1. Map of the bedrock topography (compiled by J. Straume and V. Juškevičs; supplemented by E. Tavast, A. Gaigalas, and M. Melešytè)

1 denudation remnants; 2 escarpments; 3 buried ancient valleys; 4 isohypses of sub-Quaternary surface; 5 Baltic Sea depression (below $0 \mathrm{~m}) ; 6$ lowlands $(0-40 \mathrm{~m})$ : I South-Lithuanian, II Middle-Lithuanian, III Middle-Latvian, IV West-Kurzeme, V West-Estonian, VI East-Estonian; 7 plateaus $(40-80 \mathrm{~m})$ : VII Kurzeme-Žemaitija, VIII East-Baltic, IX North-Estonian; 8 uplands (over $80 \mathrm{~m}$ ): X Latgale, XI EastKurzeme, XII Vidzeme, XIII Haanja, XIV Pandivere. 
formations, which are mainly related to the slopes of bedrock elevations and bedrock depressions.

A net of deep valleys (Abja Valley in Estonia $207 \mathrm{~m}$, Utalinka in Lithuania $259 \mathrm{~m}$, Akniste in Latvia $310 \mathrm{~m}$ ) was cut into the bedrock during preglacial and interglacial times (Fig. 1). These valleys were deepened by glaciers and subglacial streams. Frequently they are related to linear tectonic disturbances.

The deposits of ancient valleys are the most suitable objects for stratigraphic studies because they contain less erratics than upland deposits (Raukas \& Gaigalas, 1993).

\section{PRESENT TOPOGRAPHY}

As part of the vast East-European Plain the territory under consideration is characterized by a flat surface topography with small absolute and relative heights. The highest point of the area - SuurMunamägi Hill $(317.6 \mathrm{~m})$ - is located on the Haanja Upland in Estonia. In the topography hilly heights and slightly undulating plains predominate. Among the highlands the so-called insular heights, several thousand square kilometres in area, prevail. These heights are mainly composed of glacial and aqueoglacial deposits and their development is related to the inherited accumulative activity of glaciers over the Pleistocene epoch. They form submeridional systems of two to four heights that are dissected by lowlands and project high above their surroundings (Аболтиньш et al., 1989). Widespread in the EastEuropean Plain, they are practically absent elsewhere in the world. According to the structure they are classified as bedrock (thin Quaternary cover) and accumulative (thick Quaternary cover) heights. The heights have usually a bedrock core and are composed of several till beds with related intermorainic aqueoglacial deposits.

The explanation of the formation of insular heights is among the most prominent results of the Baltic Quaternary geologists in recent years. These heights developed between active ice flows during the course of subglacial, englacial, marginal, and stagnant ice stages (Аболтиньш et al., 1989). The highest, central parts of the heights are occupied by the so-called primary massifs with a complicated structure. The specific dome-shaped high $(20-50 \mathrm{~m})$ hills in the central part that consist of dislocated glaciofluvial deposits were termed dauguls by Latvian geomorphologists (Аболтиньш, 1989; Zelčs, 1993). Primary massifs are often accompanied by plateau-like hills that have a glaciolacustrine (varved clays) cover and steep $\left(12-30^{\circ}\right)$ slopes. The high central parts of the heights are surrounded by irregular hummocky relief. In the insular heights formed in a near-maximum zone of the last glaciation (Latgale Heights) the clear central and peripheral zones are absent; typical are marginal ridge-like elongated forms with angular massifs in their proximal parts.

The Baltic Ridge (in South Lithuania) together with the Augšzeme Highland (in SE Latvia) forms the so-called marginal ridges (Fig. 2). Unlike insular heights, they are elongated in shape and follow the line of the ancient glacier margin. Marginal formations - end moraines, interlobate massifs, and ridges - predominate in the topography. Occasionally outwash plains occur. The formation of these forms took place under the conditions of both the stationary-dynamic state of the glacier margin with an active participation of glaciotectonic processes and in the regression-dynamic phase when the major role was played by glacigene, particularly aqueoglacial accumulation. 


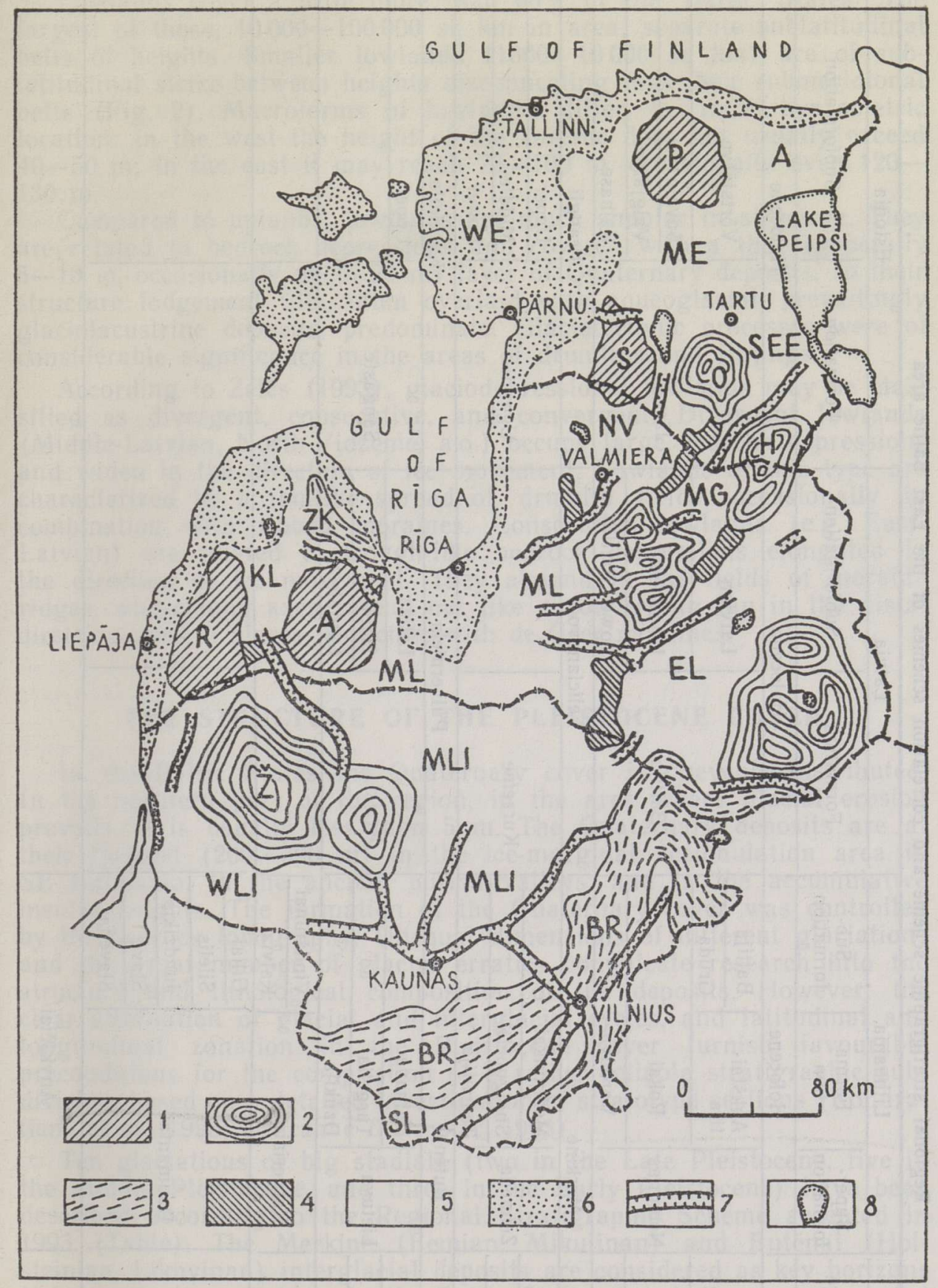

Fig. 2. Schematic geomorphologic map the Baltic States. Compiled by O. Āboltinš. Highlands: 1 insular exaration-accumulative; 2 insular glaciostructural-accumulative; 3 ice marginal glaciostructural-accumulative; 4 interlobate high. Lowlands: 5 glaciodepressional lowlands; 6 abrasion-accumulation plains of the Baltic Sea; 7 spillway valleys; 8 lakes. Major lowlands: WE West-Estonia, A Alutaguse, ME Middle Estonian, SEE Southeast-Estonian, NV North-Valmiera, MG Middle-Gauja, ML Middle-Latvian, EL East-Latvian, MLI Middle-Lithuanian, WLI West-Lithuanian, SLI South-Lithuanian, KL Kursa (Venta). Major highlands: R Rietumkursa, A Austrumkursa, ZK Ziemelkursa, S Sakala, P Pandivere, O Otepää, H Haanja (together witl Aluksne), V Vidzeme, L Latgale, Z Žemaitija, BR Baltic Ridge (together with Augšzeme). 


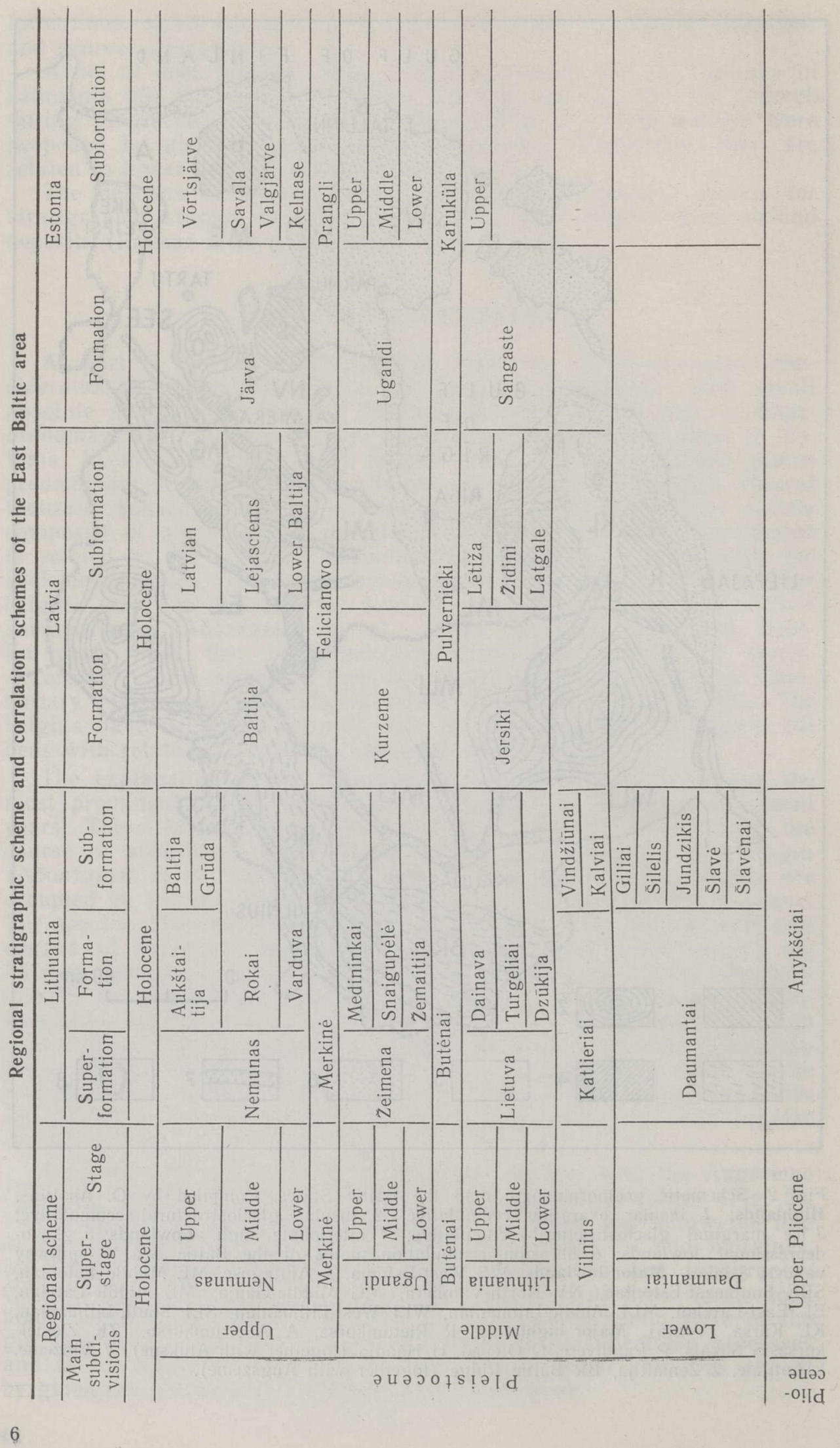


Lowlands cover a little more than $60 \%$ of the Baltic States. The largest of those, $10000-100000 \mathrm{sq} \mathrm{km}$ in area, separate sublatitudinal belts of heights. Smaller lowlands $(1000-10000 \mathrm{sq} \mathrm{km})$ are of sublatitudinal strike between heights disconnecting thus their submeridional belts (Fig. 2). Macroforms of lowlands differ in their hypsometric location: in the west the height of the surface does not usually exceed $40-50 \mathrm{~m}$; in the east it may reach $70-100 \mathrm{~m}$, occasionally even $120-$ $130 \mathrm{~m}$.

Compared to uplands, lowlands are much simpler in structure. They are related to bedrock depressions and covered with a thin (generally 5-10 m, occasionally up to $20 \mathrm{~m}$ ) layer of Quaternary deposits. In their structure lodgement tills, often overlaid with aqueoglacial, prevailingly glaciolacustrine deposits, predominate. Glaciotectonic processes were of considerable significance in the areas of drumlins and flutings.

According to Zelčs (1993), glaciodepressional lowlands may be classified as divergent, consecutive, and convergent. Divergent lowlands (Middle-Latvian, North-Vidzeme, a.o.) occupy large bedrock depressions and widen in the direction of ice movement. Lowlands of this type are characterized by a fan-like spread of drumlin fields, occasionally in combination with ribbed moraines. Consecutive lowlands (e.g. EastLatvian) are related to trough-like bedrock depressions elongated in the direction of ice movement. They abound in the fields of moraine ridges, whose long axes spread out like a converging fan in the distal direction and, in places, associate with de Geer moraines.

\section{THE STRUCTURE OF THE PLEISTOCENE COVER}

In the Baltic States the Quaternary cover is unevenly distributed. In the northern part of the region, in the area where glacial erosion prevails, it is usually less than $5 \mathrm{~m}$. The Quaternary deposits are at their thickest $(200-300 \mathrm{~m})$ in the ice-marginal accumulation area in SE Lithuania, in the ancient buried valleys, and in the accumulative insular heights. The formation of the Quaternary cover was controlled by the bedrock topography. Unequal dimensions of different glaciations and the great number of glacial erratics complicate research into the structure and lithological composition of the deposits. However, the clear alternation of glacial and interglacial cycles, and latitudinal and longitudinal zonation in the Pleistocene cover furnish favourable preconditions for the compilation of a rather reliable stratigraphic subdivision, based on a detailed investigation of stratotype sections (Kondratienė et al., 1993; Гайгалас \& Раукас, 1993).

Ten glaciations or big stadials (two in the Late Pleistocene, five in the Middle Pleistocene, and three in the Early Pleistocene) have been described according to the Regional Stratigraphic Scheme accepted in 1993 (Table). The Merkinè (Eemian, Mikulinan) and Butènai (Holsteinian, Likhvinan) interglacial deposits are considered as key horizons for stratification (Table). In the Baltic States they both are represented by interglacial marine and continental lacustrine-boggy deposits and clearly differ in palynological data (Liivrand, 1991). The spore and pollen spectra of all other intermorainic sections are not yet clear. Those sediments often contain rebedded pollen or are predominantly distributed as glacial erratics. This circumstance considerably complicates the correlation and dating of glacial strata (Raukas \& Gaigalas, 1993). In the Ionionys (South Lithuania) stratotype section of the Merkine interglacial, an optically stimulated (OSL) age of about 114000-70000 years was obtained (Gaigalas \& Hütt, 1993). 
Dating of fresh-water molluscs in the same section of the oak zone of the Merkine interglacial by the electron spin resonance (ESR) method yielded the age of 110000 years (Гайгалас et al., 1994). The ESR dates of molluscs for the Butenaian interglacial were 355000-307000 in the Naravai section and $455000-307000$ in the Gailiūnai outcrop (Гайгалас et al., 1994).

The Table shows that the stratigraphic schemes of Estonia, Latvia, and Lithuania differ considerably from one another. In the nearest years to come serious efforts will be needed to gain better understanding and agreement in stratigraphy. Most probably, the problem can be solved by comprehensive investigation of the type sites in the border areas of the three states.

\section{DEGLACIATION OF THE TERRITORY}

During all glaciations the territory of the Baltic States was greatly affected by the Baltic and Peribaltic ice flows, which were of different rates at different stages. The flows differed on lobes and tongues of the glaciers, whose location was rather stable during all the glaciations due to the peculiarities of the bedrock topography. The areas of accumulation and glacial erosion remained likewise stable.

Evidently, the ice sheet of the last (Nemunas, Valdaian, Vistulian, Weichselian) glaciation did not reach as far as southeastern Lithuania (Гайгалас et al., 1985; Гайгалас, 1988). The Early and Middle Weichselian ice-free interval has been identified in many sites. The last glacial maximum in the Baltic States occurred between 22000 and 18000 years BP (Gaigalas et al., 1993).

Three main stages in the last deglaciation of the Baltic area were established by de Geer (1940). These have been dated by varve counting and by the ${ }^{14} \mathrm{C}$ method. Serebryanny and Raukas (Серебрянный \& Payкас, 1966, 1970) described the intervals known as the Daniglacial $(20000-13000 \mathrm{BP})$, Gotiglacial (13000-10000 BP), and Finiglacial $(10000-8000 \mathrm{BP})$ as episodes with distinctly different palaeoglaciological and environmental conditions.

The eastern Baltic area was freed from the continental ice in Daniand Gotiglacial times about 18000 to 11000 years ago. Against the background of a gradual climatic warming probably remarkable cooling periods occurred causing halts or even advances of degrading ice cover marked in the nature by distinct ice marginal formations (Fig. 3). The Daniglacial episode was characterized by severe climatic conditions and an extensive ice cover. Marginal heights with a thick cover of glacial deposits were formed in the marginal areas of the glacier, and numerous big marginal valleys and sandur fields developed. Differentiated accumulation of glacial deposits as insular heights on ice-divides and accumulative and erosional formations between ice streams was typical of the Gotiglacial episode.

The age of the Luga (Haanja, North-Lithuanian) stage and, correspondingly, the boundary between the Dani- and Gotiglacial, was established at 13200 years BP (Пуннинг et al., 1968) as a result of the dating of Rauna interstadial deposits in central Latvia (13390 \pm 500 : Mo-196; $13250 \pm 160$ : TA-177; $13320 \pm 250$ : Ri-39). In Latvia several new intermorainic interstadial sections with rather similar ${ }^{14} \mathrm{C}$ ages have been discovered recently: Lidumnieku (13 080 \pm 60 : Лy-668A; $12780 \pm 100$ :

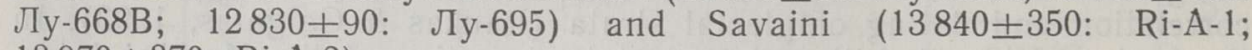
$13970 \pm 370:$ Ri-A-2).

In the Raunis section interstadial sand with alternating layers of silt and clay containing peat and plant remains lies between two layers 


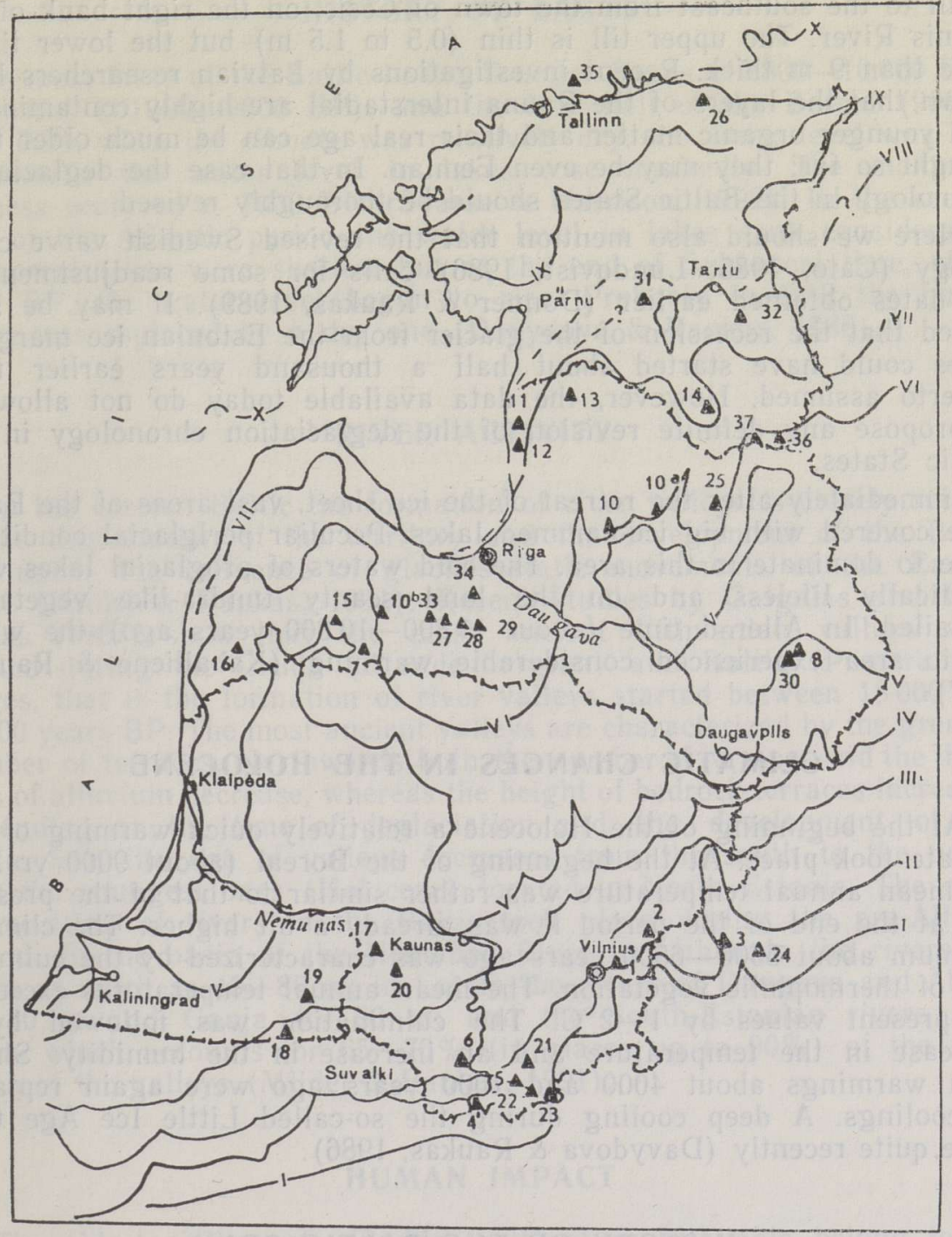

Fig. 3. The most important ice marginal zones, interstadial and interphasial sections in the territory of the Baltic States. Compiled by O. Āboltinš, A. Gaigalas, M. Melešyte, and A. Raukas.

Stages: I Brandenburgian (Gruda); II Frankfurthian (Žiogeliai); III Pomeranian (Aukštaičiai); IV South-Lithuanian; V Middle-Lithuanian; VI Luga (North-Lithuanian, Linkuva, Haanja); VII Otepää (Pliens); VIII Sakala (Valdemarpils); IX Pandivere (Neva); X Palivere. Sections: 1 Antaviliai; 2 Buivydžiai; 3 Kamariškes; 4 Druskininkai; 5 Mančiagire; 6 Krikštonys; 7 Lieclautse; 8 Burzava; 9 Kanini; 10 Rauna; 11 Bridagi; 12 Upitès; 13 Aloja; 14 Kurenurme; 15 Saldus; 16 Priekule; 17 Nopaitis; 18 Manturiai; 19 Gumbinè (Gusev); 20 Gabiauriškis; 21 Pamerkès; 22 Zervynos; 23 Rudnia; 24 Studenets; 25 Dulupite; 26 Kunda; 27 "Progress"; 28 "Sarkanais Mals"; 29 Tetele; 30 Rezekne; 31 Viljandi; 32 Tartu; 33 Kalnčiems; 34 "Purmali"; 35 Prangli; 36 Viitka; 37 Petruse, 
of till to the southeast from the town of Cēsis, on the right bank of the Raunis River. The upper till is thin $(0.5$ to $1.5 \mathrm{~m})$ but the lower till is more than $9 \mathrm{~m}$ thick. Recent investigations by Latvian researchers have shown that the layers of the Rauna interstadial are highly contaminated with younger organic matter and their real age can be much older than thought so far; they may be even Eemian. In that case the deglaciation chronology in the Baltic States should be thoroughly revised.

Here we should also mention that the revised Swedish varve chronology (Cato, 1985; Lundqvist, 1986) calls for some readjustment of the dates obtained earlier (Donner \& Raukas, 1989). It may be suggested that the recession of the glacier from the Estonian ice marginal zones could have started about half a thousand years earlier than hitherto assumed. However, the data available today do not allow us to propose any definite revision of the deglaciation chronology in the Baltic States.

Immediately after the retreat of the ice sheet, vast areas of the Baltic were covered with big ice-dammed lakes. Peculiar periglacial conditions came to dominate in this area. The cold waters of proglacial lakes were practically lifeless and on the land scanty tundra-like vegetation prevailed. In Allerød time (about 11800-10800 years ago) the whole Baltic area experienced considerable warming (Kabailienè \& Raukas, 1987).

\section{CLIMATIC CHANGES IN THE HOLOCENE}

At the beginning of the Holocene a relatively quick warming of the climate took place. At the beginning of the Boreal (about $9000 \mathrm{yr}$ BP) the mean annual temperature was rather similar to that of the present, and at the end of the period it was already a bit higher. The climatic optimum about 5500 - 6500 years ago was characterized by the culmination of thermophilic vegetation. The mean annual temperatures exceeded the present values by $1-2{ }^{\circ} \mathrm{C}$. The culmination was followed by a decrease in the temperature and an increase in the humidity. Shortterm warmings about 4000 and 1000 years ago were again replaced by coolings. A deep cooling during the so-called Little Ice Age took place quite recently (Davydova \& Raukas, 1986).

\section{HISTORY OF THE BALTIC SEA}

About 12000 years ago local ice-dammed lakes joined to form the Baltic Ice Lake. Approximately 10300 years ago its waters broke through to the Atlantic to form the more or less fresh-water Yoldia Sea. Near the eastern Baltic coast it was practically fresh. These were complicated processes, which triggered profound changes in the natural conditions all over the area. A new isolation from the ocean some 9300 years ago (Ancylus Lake) and the reunion with the ocean (Litorina Sea 80004000 BP, Limnea Sea from 4000 BP up to the present) led to obvious changes in the ecosystem and the salinity of water. Because of differences in neotectonic movements the ancient coastal formations are located tens of metres above water level in the northern and central Baltic, while the synchronous coastal formations in the southern Baltic lie tens of metres below sea level. The sea transgressions culminated at different times depending on the uneven tectonic movements (Raukas, 1991). A good overview of the history of the Baltic can be found in two recent generalizations (Donner \& Raukas, 1988; Раукас \& Хюваринен, 1992). 


\section{HISTORY OF LAKES}

In most lakes of the Baltic in the Younger Dryas (10800-10000 BP), Preboreal (10000-9000 BP), and the first half of the Boreal (9000$8000 \mathrm{BP}$ ), when the climate was relatively dry, the water level was low. Afterwards the water level in lakes rose markedly. The maximum wetness occurred c. 7000 BP (Saarse \& Harrison, 1992). In the second half of the Atlantic period the water level in lakes sank considerably. Subboreal lakes were shallow but at the end of Subboreal time, about $3000 \mathrm{BP}$, the water level began to rise. Probably in SA2 the humid phase was replaced by a dry one (Davydova \& Raukas, 1986).

\section{RIVER ACTIVITY}

In the eastern Baltic the formation of river valleys is closely related to the deglaciation of the territory and the development of the Baltic Sea under the influence of glacioisostatic movements of the Earth's crust (Miidel \& Raukas, 1991). Recent studies by Gaigalas and Dvareckas (1987) show that the most ancient Lithuanian valleys were formed during the Gruda (Brandenburgian) and Baltic (Pomeranian) stages, that is the formation of river valleys started between 18000 and 16000 years BP. The most ancient valleys are characterized by the greatest number of terraces. Northwards both the number of terraces and the thickness of alluvium decrease, whereas the height of bedrock terraces increases. Depending on the time of deglaciation and the development of the Baltic Sea, the age of valleys decreases from the south to the north, with the youngest ones (Holocene) located in North Estonia. The main downcutting of rivers in the Baltic took place during the pre-Allerød period. In the basin of the Nemunas River in Lithuania the rivers cut down as much as $40-80 \mathrm{~m}$; in Latvia the rivers of Daugava and $\bar{A}$ bava $20-40 \mathrm{~m}$ and Gauja $40-60 \mathrm{~m}$; and the South-Estonian rivers 20 $40 \mathrm{~m}$, which accounts for $65-70 \%$ (in places up to $90 \%$ ) of the total depth of the valleys (Miidel \& Raukas, 1991).

\section{HUMAN IMPACT}

The oldest settlements (Swidry culture) in Lithuania belong to the Late Palaeolithic (10th-9th centuries BC). Even the northernmost part of the area - Estonia - has been inhabited throughout the Holocene (Pulli settlement $9575 \pm 115 \mathrm{BP}$ ). However, man began to exert more serious impact on nature at the beginning of the Bronze Age about 1500 years BC, when land cultivation gained importance alongside hunting and fishing. Today millions of hectares of land have been drained, the water table in hundreds of lakes has been regulated, and the natural river regime completely destroyed in many regions. As a result of land reclamation the density of the Lithuanian river network increased from $0.4 \mathrm{~km} / \mathrm{km}^{2}$ in the $1930 \mathrm{~s}$ to $0.98 \mathrm{~km} / \mathrm{km}^{2}$ in the $1960 \mathrm{~s}$ and within the last decades it has increased one and a half times (Вайткявичюс \& Каваляускас, 1984).

In the drainage of the Kasari River, Estonia, the length of the artificial canals and dredged river channels accounts for $77 \%$ of the total length of the flowing water basins in the drainage of the Kasari River (Veering, 1983). The northeastern part of Estonia with its rich mineral resources is the area under the highest pollution load in the Baltic. In 1993, 14.9 million tons of oil shale was produced. Out of the 
total territory of 10000 hectares spoiled by mining activities, 8330 hectares had been reclaimed by 1 January 1992. Most of this area has been reforested and 110 hectares returned to agricultural use. However, these lands are far from being of top quality.

\section{TASKS FOR THE FUTURE}

Currently, the Baltic scientists together with foreign experts are engaged in elaborating scientifically motivated recommendations for the economic and social development of the area. Therefore, comprehensive investigations of the topography, bedrock, Quaternary sediments, and ground water should be carried out. Since a great number of relief forms composed of Quaternary sediments are unique natural objects, motivated recommendations are urgently needed for their protection. An important task is the change-over from East-European standards to West-European ones. To protect the mineral resources we must ensure that depletive mining will be carried out with minimum losses, the output will be utilized rationally, and the production waste will be disposed appropriately. More attention should be paid to the protection of seacoasts and the investigation of offshore sediments.

\section{REFERENCES}

Cato, I. 1985. The definitive connections of the Swedish geochronological time scale with the present, and the new date of the zero year in Döviken, northern Sweden. - Boreas, 14, 117-122.

Davydova, N. and Raukas, A. 1986. Geological development of large lakes of the humid zone in the European part of the Soviet Union, and Holocene climatic changes on the basis of lake sediment data. - J. Biogeogr., 13, 173-180.

de Geer, G. 1940. Geochronologia suecica principles. - Kgl. Svenska vetenskaps Akademiens Handlingar, ser. 3, 18, 6 .

Donner, J. and Raukas, A. (eds.). 1988. Problems of the Baltic Sea History. - Annales Academiae Scientiarum Fennicae, Ser. A. III. Geologica-Geographica, 148. Helsinki.

Donner, J. and Raukas, A. 1989. On the geological history of the Baltic Ice Lake. Proc. Estonian Acad. Sci. Geol., 38, 3, 128-137.

Eichwald, E. 1853. Lethaea Rossica ou Paléontologie de la Russie. Dernière période. Vol. 3. Stuttgart, 533.

Gaigalas, A. and Dvareckas, V. 1987. Geomorphological structure and development of river valleys during the last glaciation and Holocene in the South Peribaltic area. - In: Raukas, A. and Saarse, L. (eds.). Palaeohydrology of the temperate Zone I. Rivers and Lakes. Valgus, Tallinn, 99-110.

Gaigalas, A. and Hütt, G. 1993. Optically stimulated luminescence (OSL) dating of the last climatic macrocycle of the Pleistocene in Lithuania. - In: Geochronological and Isotope-geochemical Investigations. Vilnius, 18.

Gaigalas, A., Satkunas, J., Petrošius, R. and Banys, J. 1993. Radiocarbon age of maximum Nemunas glaciation in Lithuania. - In: Geochronological and Isotope-geochemical Investigations. Vilnius, 21.

Grewingk, C. 1879. Erläuterungen zur zweiten Augabe der geognostischen Karte Liv-, Est- and Kurlands. - Arch. Naturk. Liv-, Ehst und Kurland. Dorpat, Ser. 8, 1, 343-466.

Hausen, H. 1913. Uber die Entwicklung der Oberflächenformen in den russischen Ostseeländern und angrenzenden Gouvernements in der Quartärzeit. - Fennia, 34,3 . 
Kabailienė, M. and Raukas, A. 1987. Stratigraphy of lake and bog deposits and climatic changes in the late-glacial and Holocene in the Soviet Baltic Republics: A review. - Boreas, 16, 125-131.

Kondratiene, O. et al. 1993. Catalogue of Quaternary Stratotypes of the Baltic Region. Lithuanian Geological Institute, Vilnius.

Liivrand, E. 1991. Biostratigraphy of the Pleistocene Deposits in Estonia and Correlation in the Baltic Region. Stockholm University, Department of Quaternary Research. Report 19.

Lundqvist, J. 1986. Late Weichselian glaciation and deglaciation in Scandinavia. Quaternary Science Reviews, 5, 269-292.

Miidel, A. and Raukas, A. 1991. The evolution of the river system in the East Baltic. In: Starkel, L., Gregory, H. J. and Thornes, J. B. (eds.). Temperate Palaeohydrology. John Wiley and Sons Ltd., Chichester, 365-380.

Munthe, H. 1910. Studier öfver Gotlands senkvartära historia. Sver. Geol. Unders. Ca. 4, Stockholm.

Raukas, A. 1991. Transgressions of the Baltic Sea and the peculiarities of the formation of transgressive coastal deposits. - Quaternaire, 2, 3/4, 126-130.

Raukas, A. and Gaigalas, A. 1993. Pleistocene glacial deposits along the eastern periphery of the Sc:andinavian ice sheets - an overview. - Boreas, 22, $214-222$.

Saarse, L. and Harrison, S. P. 1992. Holocene lake-level changes in the Eastern Baltic region. - In: Estonia. Man and Nature. Estonian Geographical Society, Tallinn, 6-20.

Schmidt, F. 1869. Notiz über neuere Untersuchungen im Gebiete der Glacial und Postglacialformation in Estland und Schweden. - In: Helmersen, G. Studien über die Wanderblöcke und die Diluvialgebilde Russlands. Mém. Acad. Sci. St. Pétersb., ser. VII, XIV, 7, 55-59.

Veering, L. 1983. Kasari vetevõrk läbi aegade. - Eesti Loodus, 3, 183-191.

Zelčs, V. 1993. Glaciotectonic Landforms of Divergent Type in Glaciodepressional Lowlands. University of Latvia, Riga.

Аболтиньш О. 1989. Гляциоструктура и ледниковый морфогенез. Зинатне, Рига.

Аболтиньш О., Асеев А., Вонсявичюс В., Исаченков В., Можаев Б., Раукас А. 1989. Формирование и освоение ледниковых аккумулятивных островных возвышенностей. - Изв. АН ЭССР. Геол., 38, 1, 23-33.

Вайткявичюс Э., Каваляускас П. 1984. Проблемы охраны эталонов гидрографической сети. - Географический ежегодник XXI. АН ЛитССР, Вильнюс, $198-202$.

Гайгалас А. И. 1969. Генетические разновидности основных морен плейстоцена Литвы. - Материалы II научной конференции молодых ученых геологов Литвы. Вильнюс, $76-77$.

Гайгалас А. И. 1988. Геохронологическая оценка развития природной среды позднего плейстоцена и голоцена на территории Литовской ССР. - In: Изотопногеохимические исследования в Прибалтике и Белоруссии. Ин-т геологии АН ЭССР, Таллинн, 23-33.

Гайгалас А. И., Арсланов Х. А., Банис Ю. Ю. 1985. Новые данные радиоуглеродного датирования позднего плейстоцена и археологических памятников на территории Литовской ССР - - Тезисы докладов Всесоюзной конференции «Геохронология четвертичного периода», Москва, 18-21 ноября 1985 г. Москва, 36.

Гайгалас А. И., Молодьков А. Н., Мелешите М. И. 1994. Первые результаты датирования методом ЭПР бутенайских (лихвинских) и мяркинских (микулинских) межледниковых отложений в Литве. - Тезисы докладов Всесоюзной конференции по изучению четвертичного периода, Москва, 6-11 июня 1994 г. Москва, 64.

Гайгалас А., Раукас А. 1993. Проблемные вопросы стратиграфии четвертичных отложений Прибалтики. - Научные труды высших учебных заведений Литвы, 14. Детальная стратиграфия, II, 158-166. 
Гуделис В. К. 1973. Рельеф и четвертичные отложения Прибалтики. Минтис, Вильнюс.

Даниланс И. Я. 1973. Четвертичные отложения Латвии. Зинатне, Рига.

Пуннинг Я.-М. К., Раукас А. В., Серебрянный Л. Р., Стелле В. Я. 1968. Палеогеографические особенности и абсолютный возраст лужской стадии валдайского оледенения на Русской равнине. - Докл. АН СССР, 178, 4, 916-918.

Раукас А. 1978. Плейстоценовые отложения Эстонской ССР. Валгус, Таллинн.

Раукас А., Ряхни Э., Мийдел А. 1971. Краевые ледниковые образования Северной Эстонии. Валгус, Таллинн.

Раукас А., Хюваринен Х. (eds.). 1992. Геология Финского залива. АН ЭССР, Таллинн.

Серебрянный Л. Р., Раукас А. В. 1966. Трансбалтийские корреляции краевых ледниковых образований позднего плейстоцена. - In: Верхний плейстоцен. Стратиграфия и абсолютная геохронология. Наука, Москва, $12-27$.

Серебрянный Л. Р., Раукас А. В. 1970. Новые пути и методы изучения ледниковой истории Русской равнины в верхнем плейстоцене. - Географический сборник, 4. ВИНИТИ, Москва, 117-137.

\title{
BALTIMAADE KVATERNAARIGEOLOOGIA NUUDISSEISUND JA SUUNDUMUSED
}

\section{Anto RAUKAS, Ojars ĀBOLTINŠ, Algirdas GAIGALAS}

Eestis, Lätis ja Leedus on saadud rahvusvaheliselt arvestatavaid tulemusi paljudes kvaternaarigeoloogia valdkondades, eeskätt stratigraafias, litoloogias, glatsiaalgeomorfoloogias ja isotoopgeoloogilistes uuringutes. 1993. aastal on kõigis kolmes riigis kinnitatud uued Pleistotseeni, Holotseeni ja hilisglatsiaali stratigraafilised skeemid ning detailselt kirjeldatud kõiki põhilisi settetüüpe ja pinnavormide kooslusi. Ala on kaardistatud keskmises mõotkavas ja paljudes piirkondades on alanud või lõppenud suuremõõtkavaline kaardistamine. Eriti oluliseks tuleb pidada kuhjeliste saarkõrgustike ehituse ja kujunemisloo selgitamist. Aktuaalne ülesanne on metoodikate, skeemide ja legendide üleviimine lääne standarditele ning mereuuringute hoogustamine.

\section{СОВРЕМЕННОЕ СОСТОЯНИЕ И ПРЕДСТОЯЩИЕ ЗАДАЧИ ЧЕТВЕРТИЧНОЙ ГЕОЛОГИИ В ПРИБАЛТИКЕ}

\author{
Анто РАУКАС, Оярс АБОЛТИНЫШ, Альгирдас ГАИГАЛАС
}

В Эстонии, Латвии и Литве получено немало хороших результатов в разных направлениях четвертичной геологии, в частности в стратиграфии, литологии, гляциальной геоморфологии и изотопной геологии. В 1993 г. во всех трех республиках были утверждены новые стратиграфические схемы плейстоценовых, голоценовых и позднеледниковых отложений, детально описаны все основные генетические типы четвертичных отложений и форм рельефа. Территория Прибалтики покрыта среднемасштабной геологической съемкой, во многих районах начата или завершена крупномасштабная съемка. $\mathrm{K}$ весьма важным достижениям относится выяснение строения и особенностей формирования острсвных аккумулятивных возвышенностей. Актуальными задачами на будущее являются внедрение новых методик, схем и легенд, соответствующих западным стандартам, и ускорение изучения геолсгического строения морского дна. 